\title{
IMPLEMENTASI GERAKAN LITERASI PADA SEKOLAH RAMAH ANAK
}

\section{IMPLEMENTATION OF THE LITERATURE MOVEMENT AT A CHILD-FRIENDLY SCHOOL}

\author{
Meri Yuliyanti*1, Dedi Romli Triputra ${ }^{2}$ \\ 1,2, Program Studi Pendidikan Guru Sekolah Dasar, Fakultas Keguruan dan Ilmu Pendidikan, Universitas \\ Muhadi Setiabudi Brebes, Indonesia \\ e-mail: ${ }^{* 1}$ meriyuliyanti@gmail.com, 2 dediromlitriputra@gmail.com
}

\begin{abstract}
ABSTRAK
Gerakan literasi sekolah (GLS) merupakan suatu program yang telah dikeluarkan oleh pemerintah guna menumbuhkan budaya literasi dan pembiasaan perilaku positif kepada seluruh warga sekolah. Implementasi GLS diperlukan konsep sekolah yang ramah anak (SRA), agar dalam pelaksanaannya dapat berjalan secara optimal. Tujuan dalam penelitian ini untuk mendeskripsikan tahapan pelaksanaan dan penggunaan program penunjang GLS pada SRA. Jenis penelitian yang digunakan yaitu penelitian kualitatif dengan pendekatan studi kasus yang dilaksanakan di SD Negeri Brebes 03. Teknik pengumpulan data menggunakan observasi, wawancara dan dokumentasi. Teknik analisis data mengacu pada model analisis Miles dan Huberman. Hasil penelitian menunjukkan, 1) implementasi GLS pada SRA terdapat tiga tahapan yaitu tahap pembiasaan, tahap pengembangan, dan tahap pembelajaran, disetiap tahapan pelaksanaan terdapat faktor pendukung dan penghambat. 2) penggunaan program penunjang seperti, pembiasaan membaca 15 menit, perpustakaan sekolah, sudut baca ramah anak, ruang kelas yang kaya teks literasi dan ramah anak, pembuatan mading, perpustakaan keliling daerah, dan pengadaan lomba literasi, yang dalam penggunaannya tidak lepas dari konsep ramah anak dengan memperhatikan karakteristik anak, kebutuhan sekolah, dan ketersediaan prasarana pendukung yang ada di SD Negeri Brebes 03.
\end{abstract}

Kata kunci: gerakan literasi, sekolah ramah anak

\begin{abstract}
The school literacy movement (GLS) is a program that has been issued by the government to foster a culture of literacy and habituation of positive behavior to all school members. The implementation of the $G L S$ requires the concept of a child-friendly school (SRA), so that in its implementation it can run optimally. The purpose of this study is to describe the stages of implementation and use of GLS support programs in SRA. The type of research used is qualitative research with a case study approach which was carried out at SD Negeri Brebes 03. Data collection techniques used observation, interviews and documentation. The data analysis technique refers to the Miles and Huberman analysis model. The results showed, 1) the implementation of GLS in SRA there were three stages, namely the habituation stage, development stage, and learning stage, at each stage of implementation there were supporting and inhibiting factors. 2) the use of supporting programs such as the habit of reading for 15 minutes, school libraries, child-friendly reading corners, classrooms rich in literacy and child-friendly texts, making wall magazines, regional mobile libraries, and holding literacy competitions, which in their use cannot be separated from the friendly concept. children by taking into account the characteristics of children, school needs, and the availability of supporting infrastructure in SD Negeri Brebes 03.
\end{abstract}

Keywords: literacy movement, child friendly school 


\section{PENDAHULUAN}

Setiap individu harus memiliki kompetensi literasi yang baik, sehingga seorang individu dapat memahami suatu makna dari informasi dan menggunakan kembali informasi tersebut dengan bijak. Melalui kemampuan literasi yang baik, masyarakat tidak akan ada lagi yang buta informasi, apalagi masyarakat buta aksara [1]. Literasi yaitu suatu proses membaca, berfikir, berbicara, mendengarkan dan berpendapat secara intensif yang kemudian dapat diaktualisasikan dalam bentuk karya. Mempunyai kemampuan literasi yang baik, pandangan masyarakat akan jauh lebih berkembang, lebih bijak dalam menanggapi segala bentuk informasi yang telah di dapat, dan dapat menganalisis informasi tersebut dengan cerdas.

Membaca adalah salah satu kegiatan yang mendukung literasi. Melalui kegiatan membaca peserta didik akan dapat memahami banyak hal. Kegiatan membaca yang efektif perlu disertai minat baca yang tinggi. Penelitian menunjukkan, minat baca peserta didik masih rendah hal ini dapat terlihat dari berbagai hal seperti kecenderungan menggunakan internet sebagai sumber referensi dan kurang disukai dan kurang dipahaminya soal-soal evaluasi yang berbentuk deskripsi panjang [2]. Minat dan kemampuan membaca sangat berkaitan erat khususnya dalam kegiatan memahami teks bacaan [3]. Melalui pemahaman teks bacaan peserta didik akan memperoleh informasi. Disamping itu, hal-hal yang dibaca oleh peserta didik tentu akan mempengaruhi sikap ilmiah peserta didik [4]. Oleh sebab itu, pemilihan bahan bacaan yang tepat perlu dilakukan agar minat baca peserta didik dapat berkembang dan dapat mendukung gerakan literasi sekolah

Gerakan literasi sekolah (GLS) sendiri merupakan program yang dicanangkan oleh Kementerian Pendidikan Dan Kebudayaan pada tahun 2015. Program tersebut sebagai upaya dalam meningkatkan kesadaran masyarakat dalam menumbuhkan budaya literasi di sekolah. Implementasi GLS dipergunakan sebagai suatu program pembudayaan literasi yang tepat dan mudah dilaksanakan di lingkungan sekolah, yang dapat diterapkan secara sistematis, menyeluruh pada semua komponen sekolah, dan dikelola secara profesional oleh lembaga yang terpercaya [1]. Pengembangan budaya literasi di sekolah dipengaruhi oleh fasilitas, suasana belajar, dan kenyamanan peserta didik dalam pembelajaran. Kenyamanan ini akan terwujud apabila fasilitas sekolah yang disediakan ramah terhadap anak seperti lingkungan yang asri, bersih dan tidak membahayakan peserta didik [5].

Pelaksanaan GLS tentu tidak lepas dari tahapan-tahapan yang mendukungnya. Terdapat tiga tahapan pelaksanaan GLS meliputi pembiasaan, pengembangan, dan pembelajaran literasi [6]. Setiap tahapan didukung oleh kegiatan tertentu yang dikembangkan oleh sekolah dengan melihat karakteristik peserta didik. Pertama tahap pembiasaan, pada tahapan ini, hal yang dilakukan yaitu penumbuhan minat baca peserta didik. Sekolah menyediakan berbagai koleksi buku dan bahan bacaan selain buku pelajaran yang dapat menarik minat baca peserta didik dan meningkatkan kegiatan literasi peserta didik [6]. Kedua tahap pengembangan, tahapan ini bertujuan untuk meningkatkan kemampuan dalam hal memahami bacaan dan mengaitkannya dengan kehidupan sehari-hari, berpikir dengan kritis, dan mengalisis kemampuan komunikasi secara kreatif melalui kegiatan menanggapi buku pengayaan [6]. Selanjutnya yang ketiga yaitu tahap pembelajaran, tahapan ini sekolah dapat menyelenggarakan berbagai macam kegiatan dengan tujuan untuk mempertahankan minat baca dan meningkatkan kecakapan literasi dari peserta didik melalui buku-buku pengayaan dan buku teks pelajaran [6].

Salah satu lembaga pendidikan yang dapat memberikan fasilitas dan pemberdayaan potensi anak yaitu dengan menerapakan sekolah ramah anak (SRA). SRA harus memiliki prinsipprinsip dalam perlindungan anak, yaitu; tanpa diskriminasi, tanpa kekerasan, hak tumbuh dan berkembang, kepentingan terbaik bagi anak dan penghargaan terhadap pendapat anak, yang dapat diintegrasikan ke dalam bidang-bidang implementasi, yakni;kurikulum, manajemen, kebijakan dan peraturan sekolah, prasarana dan lingkungan, serta relasi sehari-hari antara pemangku kepentingan [7]. GLS dan SRA terdapat keterkaitan yang saling berhubungan kuat satu dengan yang lainnya. Sesuai dengan pernyataan tersebut, baik dalam konsep dan pelaksanaan serta program yang mendukung keduanya memiliki keterkaitan. Hubungan antara keduanya haruslah 
berjalan dengan target pencapaian yang sesuai, seperti halnya dalam pelaksanaan gerakan literasi yang membutuhkan bahan bacaan berupa buku, poster, majalah, dan teks bacaan lainnya, haruslah ramah anak. Bahan bacaan yang disediakan tidak mengandung unsur SARA, provokatif, dan pornografi.

SD Negeri Brebes 03 sudah melaksanakan program pemerintah antara lain yaitu, menerapkan kurikulum 2013, gerakan literasi sekolah, sekolah ramah anak, dan menjadi sekolah rujukan nasional pada tahun 2016, hal ini di sampaikan oleh kepala SD Negeri Brebes 03 yang telah melalui tahap verifikasi oleh kementerian pendidikan dan kebudayaan kabupaten Brebes. Di sekolah ini, program literasi dilaksanakan untuk mendongkrak dan terus meningkatkan minat baca warga sekolah, terutama guru dan peserta didik. Sebagai langkah awal, pihak sekolah terus berkomitmen untuk melaksanakan gerakan membaca 15 menit sebelum pembelajaran dimulai. Bersamaan dengan gerakan tersebut, terdapat beberapa hal menarik yang menjadi perhatian bagi peneliti. Sekolah tersebut telah melaksanakan kegiatan positif yang berkaitan dengan literasi seperti, lomba baca puisi dan lomba mengarang cerita. Namun, dalam pelaksanaannya peneliti tertarik untuk mengkaji lebih lanjut terkait dengan pelaksanaan kegiatan GLS tersebut yang disesuaikan dengan konsep SRA.

\section{METODE PENELITIAN}

Penelitian ini dilaksanakan di sekolah dasar yang sudah menerapkan GLS dan SRA di Kabupaten Brebes. Salah satu sekolah dasar yang sudah menerapkan kedua program tersebut adalah SD Negeri Brebes 03, yang berlokasi di Jalan Raya Pantura Blok I Nomor 34, Pengembon, Kecamatan Brebes, Kabupaten Brebes. Penelitian dilaksanakan dilaksanakan selama 6 bulan, yaitu dari bulan Februari 2021 sampai dengan Juli 2021. Penelitian ini merupakan penelitian kualitatif dengan pendekatan studi kasus yang akan menggali, mendeskripsikan, dan menganalisis implementasi Gerakan Literasi pada sekolah ramah anak. Sumber data yang digunakan ada dua, yaitu sumber data primer dan sumber data sekunder. Sumber data primer terdiri dari kepala sekolah, guru kelas V, pustakawan, peserta didik dan orang tua peserta didik di SD Negeri Brebes 03. Sementara sumber data sekunder didapat melalui kajian pustaka dengan mencari referensi buku dan jurnal ilmiah, dokumentasi, maupun melakukan observasi secara langsung di SD Negeri Brebes 03. Peneliti memfokuskan penelitian ini pada Guru dan Peserta didik kelas V SD Negeri Brebes 03 pada semester genap tahun ajaran 2020/2021, serta fokus penelitian pada studi kasus implementasi gerakan literasi pada sekolah ramah anak di SD Negeri Brebes 03. Teknik pengumpulan data dalam penelitian ini menggunakan observasi, wawancara dan dokumentasi.

Uji keabsahan data menggunakan triangulasi sumber dan triangulasi teknik. Sedangkan analisis data ini mengacu pada model analisis Miles \& Huberman, analisis data penelitian kualitatif meliputi reduksi data (data reduction) yang sesuai dengan rumusan masalah dan pertanyaan penelitian. Penyajian data (data display) dilakukan dengan mendeskripsikan data hasil penelitian yang telah didapatkan dan mengaitkannya dengan teori yang relevan. Terakhir penarikan kesimpulan (verifying) akan menjawab rumusan masalah dan pertanyaan penelitian dari penyajian data yang sudah dilakukan. 


\section{HASIL DAN PEMBAHASAN}

\section{Hasil Penelitian}

\section{Tahapan Pelaksanaan Gerakan Literasi Di Sekolah Dasar Ramah Anak}

Penelitian ini dilakukan di SD Negeri Brebes 03 yang merupakan salah satu sekolah rujukan di Kabupaten Brebes yang didalamnya sudah menerapkan program GLS dan SRA dengan baik. Dalam pelaksanaannya tersebut SD Negeri Brebes 03 selalu berupaya dengan baik agar penerapan program GLS berjalan dengan optimal yang disesuaikan dengan penerapan konsep SRA. Hasil penelitian menunjukkan bahwa Kepala sekolah, Guru dan Pustakawan sekolah sudah memahami makna literasi dan melaksanakan program GLS yang disesuaikan dengan penerapan SRA, namun pada Orang tua dan Peserta didik kelas V belum sepenuhnya memahami makna dari literasi dan pelaksanaan program GLS di sekolah.

Berkaitan dengan hal tersebut dalam menerapkan program GLS yang harus disesuaikan dengan program SRA pihak sekolah telah melakukan beberapa tahapan yang disesuaikan dengan pembelajaran. Hasil wawancara dengan kepala sekolah yang menyatakan bahwa:

"Awalnya itu mbak kami dengan anak-anak membaca buku-buku perpustakaan yang ada di setiap kelas. Jadi setiap hari itu sebelum belajar anak-anak dan guru membaca buku kemudian diriview dan dirangkum oleh anak-anak dan dicatat oleh guru hari, tanggal, dan judul buku".

Dari hasil wawancara dapat diketahui bahwa pertama tahapan pelaksaaan GLS di sekolah, kepala sekolah dengan dewan guru bersama-sama menyiapkan prasarana pendukung seperti perpustakaan dan bahan bacaan terlebih dahulu kemudian mengaplikasikan melalui tahap pembiasaan kepada seluruh peserta didik. Selain itu, Guru juga menerapkan kegiatan literasi didalam pembelajaran seperti halnya kegiatan membaca 15 menit sebelum pembelajaran dimulai. Kedua yaitu tahap pengembangan, hal ini ditandai dengan adanya koleksi buku-buku yang ramah anak di perpustakaan sekolah, dan terdapat lembar penilaian maupun pengamatan untuk mengamati kegiatan membaca peserta didik. Hasil wawancara dengan kepala sekolah yang menyatakan bahwa:

"Alkhamdulillah sudah mbak, buku-buku disini kebanyakan memang tentang buku pelajaran. Buku non pelajaran ada hanya beberapa seperti buku cerita rakyat, dongeng, sejarah, dll. Saya rasa sudah ramah anak ya mbak karena bacaan nya juga tidak mengandung unsur-unsur kejahatan dan kekerasan".

Contoh buku non pelajaran tersaji dalam gambar 1 sebagai berikut.

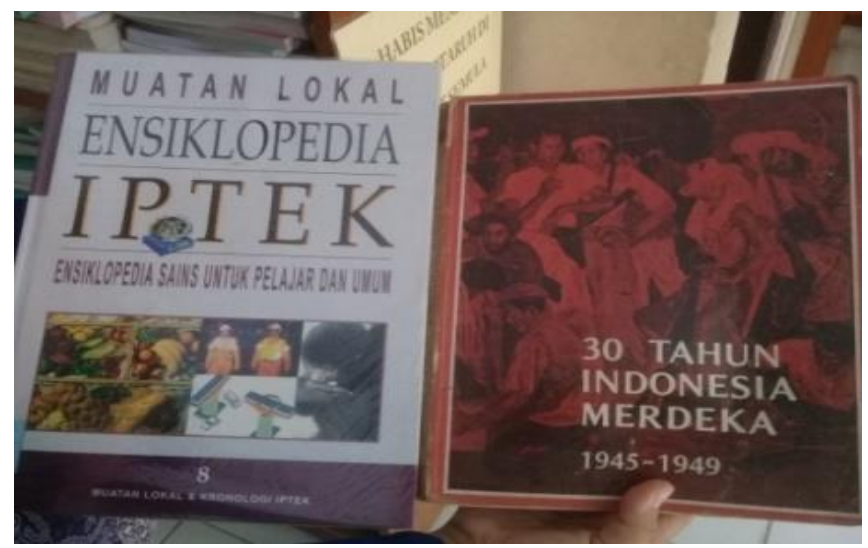

Gambar 1. Koleksi Buku Non Pelajaran di Perpustakaan SD Negeri Brebes 03

Ketiga yaitu tahap pembelajaran, pada tahapan ini ditandai dengan terdapat buku pengayaan. Pada saat pembelajaran yang berlangsung peserta didik selalu melakukan kegiatan menanggapi buku pengayaan. Hal ini berdasarkan hasil wawancara dengan guru kelas $\mathrm{v}$ yang menyatakan bahwa: 
“...Setelah itu buku yang sudah dibaca kadang di riview kadang tidak, ada pencatatan khusus untuk hal itu. Anak-anak membaca tentang pengetahuan, dongeng atau apapun yang penting ada yang dibaca."

Selain itu, terdapat area baca sekolah yang ramah anak, area baca sekolah digunakan peserta didik untuk melakukan kegiatan membaca bersama dengan teman sebaya di sekitar sekolah. kemudian terdapat penghargaan akademik yang mempertimbangkan kecakapan literasi peserta didik, biasanya guru memberikan reward atau hadiah kecil untuk peserta didik yang sudah mencapai kecakapan literasi, misalnya peserta didik rajin berkunjung ke perpustakaan sekolah, peserta didik memenangkan lomba yang berkaitan dengan literasi. Selain tahapan pelaksanaan GLS pada SRA, juga terdapat ketersediaan sarana dan prasarana pendukung dalam implementasi gerakan literasi di sekolah dasar ramah anak. Ketersediaan sarana dan prasarana pendukung dalam implementasi GLS dalam konsep SRA sebagian besar sarana dan prasarana pendukung di SD Negeri Brebes 03 sudah terpenuhi. Hanya saja ada yang jumlah nya terbatas, dan ada satu hal yang belum terpenuhi yaitu, tim literasi sekolah. Selain itu, ketersediaan sarana dan prasarana pendukung yang hanya tersedia dalam pelaksanaan offline tentunya menjadi kendala dalam penerapan GLS selama pandemi covid-19.

Implementasi GLS di sekolah dasar ramah anak terdapat faktor pendukung dalam pelaksanaannya. Pertama, partisipasi langsung dari seluruh warga sekolah. Kedua, adanya kerjasama dengan pihak luar yang ikut membantu dalam pelaksanaan kegiatan GLS. Pihak sekolah terus menjalin kerjasama dengan Perpustakaan Umum Daerah Kabupaten Brebes yang terkadang datang ke sekolah setiap dua bulan sekali yaitu pada hari selasa dan kamis. Ketiga, dalam kegiatan pembelajaran literasi terdapat lingkungan sekolah yang kondusif, walaupun letak geografis SD Negeri Brebes 03 berada dekat dengan jalan raya pantura Brebes tetapi pihak sekolah selalu mengupayakan keselamatan dan keamanan peserta didik dalam pembelajaran. Keempat, pengalaman-pengalaman yang telah dilakukan oleh Kepala sekolah menjadi contoh yang baik dan menjadi pendorong kepada peserta didik. Kelima, terdapat motivasi dan dukungan langsung dari orang tua peserta didik terhadap implementasi GLS di sekolah.

Selain faktor pendukung yang telah dijabarkan diatas, kemudian adanya faktor penghambat yang menjadi persoalan dalam implementasi GLS pada penerapan SRA di SD Negeri Brebes 03. Faktor penghambat yang pertama adalah keterbatasan jumlah koleksi buku yang ramah anak dan sebagai buku yang mulai rusak, baik yang terdapat di perpustakaan sekolah maupun di sudut baca setiap kelas. Kedua, tidak semua peserta didik mempunyai ketertarikan yang sama terhadap kegiatan literasi yang disebabkan oleh berbagai faktor salah satunya yaitu teman sebaya dan kebiasaan orang tua di rumah dalam membiasakan budaya membaca kepada anak. Ketiga, permasalahan yang selanjutnya berkaitan dengan pelaksanaan pembelajaran yang dilakukan secara daring. Pandemi covid-19 mengharuskan pembelajaran saat ini dilakukan dari rumah oleh sebab itu hal ini menjadi pokok permasalahan yang dialami oleh guru dan orang tua peserta didik. Keempat, belum adanya tim literasi sekolah secara khusus.

\section{Penggunaan Program Penunjang Gerakan Literasi Di Sekolah Dasar Ramah Anak}

Menciptakan kemampuan literasi yang baik kepada seluruh warga sekolah dapat dilakukan dengan berbagai macam cara. Salah satunya pihak sekolah terus berupaya secara bersama-sama mewujudkan program-program yang menunjang kegiatan literasi sebagai bentuk implementasi GLS, hal itu tidak lepas dari penerapan SRA yang sudah dijalankan oleh pihak sekolah. Keduanya diharapkan dapat berjalan bersamaan agar dapat menjadikan warga sekolah yang literat dan memiliki budi pekerti yang baik. Program-program penunjang yang dibuat dengan memperhatikan karakteristik anak usia dasar, kebutuhan sekolah dan ketersediaan prasarana pendukung yang ada di sekolah.

1) Program 15 menit membaca, program ini digunakan oleh guru kepada peserta didik dikelas sebelum memulai pembelajaran. Kegiatan ini dilakukan untuk menumbuhkan kebiasaan yang positif agar minat baca peserta didik dapat berkembang dengan baik.

2) Perpustakaan sekolah yang aman dan nyaman, digunakan untuk kunjungan membaca oleh peserta didik, tetapi sering kali digunakan untuk latihan lomba-lomba dan juga pembelajaran. 
3) Sudut baca ramah anak disetiap kelas, digunakan untuk menyimpan buku-buku non pelajaran yang dapat dibaca oleh peserta didik didalam kelas.

4) Ruang kelas yang kaya teks literasi dan ramah anak selalu mengutamakan kenyamanan untuk peserta didik dalam belajar. Ruang kelas yang kaya teks literasi digunakan untuk menumbuhkan minat baca peserta didik dan sebagai motivasi yang dapat dibaca oleh peserta didik.

5) Mading (majalah dinding), digunakan sebagai tempat untuk memajang hasil karya-karya peserta didik yang tidak lepas dari literasi seperti cerpen, puisi, pantun, gambar, dll.

6) Program perpustakaan keliling daerah, digunakan secara langsung oleh peserta didik untuk membaca koleksi buku terbaru. Hal ini membuat suasana baru yang diberikan oleh pihak sekolah untuk peserta didik yang bosan untuk membaca buku-buku yang sama di perpustakaan maupun sudut baca kelas.

7) Pengadaan lomba literasi, digunakan untuk mengembangkan minat dan bakat peserta didik dalam bidang literasi.

\section{Pembahasan \\ Tahapan Pelaksanaan Gerakan Literasi di Sekolah Dasar Ramah Anak}

Dari hasil penelitian menunjukkan bahwa dalam tahapan awal pelaksaaan GLS pihak sekolah bersama-sama menyiapkan prasarana pendukung seperti perpustakaan dan bahan bacaan terlebih dahulu kemudian mengaplikasikan melalui tahap pembiasaan kepada seluruh peserta didik. Sebelum adanya pandemi covid-19 dilakukan pembiasaan kegiatan 15 menit membaca sebelum pembelajaran di kelas. Kegiatan 15 menit membaca sebelum pembelajaran temasuk kedalam tahap pembiasaan [6]. Selain kegiatan tersebut, SD Negeri Brebes 03 juga terdapat bahan yang kaya teks, dan lingkungan yang kaya literasi serta ramah anak.

Tahapan implementasi GLS pada konsep SRA yang kedua yaitu adanya tahap pengembangan, hal ini berdasarkan hasil wawancara dari kepala sekolah dan pustakawan yang ditandai dengan adanya koleksi buku-buku yang ramah anak dan layak dibaca yang terdapat di perpustakaan sekolah dan pojok baca setiap kelas, dan terdapat lembar penilaian maupun pengamatan untuk mengamati kegiatan membaca peserta didik. Pada tahap pengembangan pelaksanaan GLS ditandai dengan adanya pojok baca kelas, pemanfaatan perpustakaan, tersedianya bahan bacaan, dll [8].

Selanjutnya tahapan yang ketiga yaitu tahap pembelajaran, berdasarkan hasil penelitian pada tahap ini ditandai dengan terdapat buku pengayaan, kegiatan menanggapi buku pengayaan setiap hari dilakukan oleh peserta didik pada saat pembelajaran. Selain itu, berdasarkan pernyataan dari pustakawan sekolah terdapat area baca sekolah yang ramah anak yang digunakan peserta didik untuk melakukan kegiatan membaca bersama dengan teman sebaya. Kemudian terdapat penghargaan akademik yang diberikan pihak sekolah kepada peserta didik atas tercapainya prestasi dalam kegiatan literasi.

Tahapan pelaksanaan kegiatan literasi yang sudah diterapkan mengalami hambatan dan perubahan penyesuaian terhadap kondisi pandemi covid-19. Kepala sekolah SD Negeri Brebes 03 mengatakan bahwa karena masih dalam keadaan pandemi, sekolah belum bisa melakukan pembelajaran tatap muka seperti biasa dan kegiatan literasi menjadi kurang optimal dalam pelaksanaannya. Pelaksanaan kegiatan GLS selama pandemi covid-19 tentu tidak dapat dikatakan optimal [9], karena dilakukan dari rumah dengan menggunakan sistem daring. Pembelajaran dari rumah yang dilakukan oleh peserta didik sangat membutuhkan pendampingan dari orang tua dalam pengelolaan kegiatan GLS selama pandemi covid-19 [9]. Hal ini sangat perlu dilakukan karena banyak dijumpai permasalahan yang ada seperti Peserta didik yang sulit dalam hal memahami pembelajaran, dan penumpukan informasi yang mengakibatkan kegiatan GLS kurang optimal.

Permasalahan dalam pelaksanaan GLS pada konsep SRA yang dilakukan dari rumah dapat diminimalisir dengan adanya faktor pendukung dalam menjalankan implementasi GLS yang disesuaikan dengan konsep SRA dari pihak sekolah maupun orang tua peserta didik. Faktor pendukung dalam implementasi GLS pada konsep SRA yang pertama yaitu, partisipasi langsung 
dari seluruh warga sekolah dalam memberikan motivasi dan dukungan dalam pembuatan program-program penunjang implementasi GLS pada konsep SRA [10]. Kedua yaitu adanya bentuk kerja sama dengan pihak luar. Bentuk kerja sama yang dilakukan pihak sekolah yaitu dengan Perpustakaan Umum Daerah Kabupaten Brebes, Kepala sekolah SD Negeri Brebes 03 mengatakan bahwa terkadang adanya kunjungan perpustakaan keliling yang datang langsung ke sekolah dua bulan sekali.

Ketiga, terdapat lingkungan sekolah yang kondusif untuk kegiatan pembelajaran literasi yang disesuaikan dengan konsep ramah anak. Pihak sekolah selalu mengupayakan keselamatan dan keamanan peserta didik walaupun letak sekolah dekat dengan jalan raya pantura brebes. Hal ini sesuai dengan prinsip-prinsip SRA bahwa adanya prinsip kepentingan terbaik bagi anak, kelangsungan hidup dan perkembangan, serta pengelolaan yang baik [7]. Keempat yaitu, berdasarkan pengalaman-pengalaman dari Kepala sekolah yang menjadi contoh secara langsung dan menjadi motivasi kepada peserta didik. Kelima yaitu, adanya dukungan dari orang tua peserta didik terhadap implementasi GLS di sekolah. Dukungan dan motivasi yang diberikan orang tua sangat mempengaruhi ketika kegiatan pembelajaran literasi yang dilakukan dari rumah, hal ini karena selama proses belajar dari rumah, peserta didik akan lebih banyak waktu dengan orang tua. Pola asuh yang dapat digunakan orang tua yaitu pola asuh yang demokratis, kemudian contoh nyata yang diberikan orang tua dan lingkungan yang mendukung dapat mempengaruhi keberhasilan pelaksanaan GLS dari rumah [9].

Selain faktor pendukung yang telah dijabarkan diatas, kemudian terdapat adanya faktor penghambat yang menjadi persoalan dalam implementasi GLS pada konsep SRA di SD Negeri Brebes 03. Faktor penghambat yang pertama yaitu, keterbatasan jumlah koleksi buku yang ramah anak dan sebagai buku yang mulai rusak, baik yang terdapat di perpustakaan sekolah maupun di sudut baca setiap kelas. Keterbatasan buku dapat mempengaruhi minat baca peserta didik. Kedua, tidak semua peserta didik mempunyai ketertarikan yang sama terhadap kegiatan literasi yang disebabkan oleh berbagai faktor salah satunya yaitu teman sebaya dan kebiasaan orang tua di rumah dalam membiasakan budaya membaca kepada anak, salah satu faktor penghambat GLS yaitu kurangnya motivasi peserta didik untuk membaca [8].

Ketiga yaitu, berkaitan dengan pelaksanaan pembelajaran yang dilakukan secara daring. Kesulitan sangat dirasakan oleh orang tua dalam mengawasi pembelajaran anaknya. Oleh karena itu perlu adanya komunikasi yang terbuka melalui seluler antara orang tua dengan guru kelas agar dapat membantu dalam pembelajaran dari rumah. bahwa pelaksanaan GLS yang dilakukan dari rumah sangat membutuhkan peranan penting dari orang tua, maka dari itu komunikasi adalah hal yang sangat penting dalam membantu proses pembelajaran, tanpa adanya komunikasi dan kerjasama yang baik tentu pelaksanaan GLS akan mengalami hambatan [9]. Keempat yaitu, belum adanya tim literasi sekolah secara khusus. Hal ini bertujuan untuk memastikan Gerakan Literasi Sekolah berjalan baik. Tugas dari Tim Literasi Sekolah yaitu mengatur kelancaran program literasi dengan membuat Rencana Kerja dimana terdapat jadwal kegiatan yang berkenaan dengan kegiatan literasi [8].

\section{Penggunaan Program Penunjang Gerakan Literasi Di Sekolah Dasar Ramah Anak}

Berdasarkan hasil penelitian Implementasi GLS pada konsep SRA dilaksanakan di SD

Negeri Brebes 03, Cara untuk memiliki kemampuan literasi, pihak sekolah terus berupaya secara bersama-sama membuat program-program yang menunjang kegiatan literasi sebagai wujud implementasi GLS, berikut ini beberapa penggunaan program penunjang dalam pelaksanaan GLS pada SRA.

1) Program 15 menit membaca, kegiatan ini dilakukan untuk menumbuhkan kebiasaan yang positif agar minat baca peserta didik dapat berkembang dengan baik. Melalui pembiasaan membaca maka minat dan kemampuan membaca seseorang kemudian akan muncul, sehingga mendapatkan informasi sebagai bentuk literasi dasar.

2) Perpustakaan sekolah yang aman dan nyaman, Perpustakaan sekolah SD Negeri Brebes 03 terdapat buku-buku pelajaran dan buku non pelajaran yang tersusun rapi di rak buku. 
Perpustakaan selain digunakan untuk kunjungan membaca oleh peserta didik, perpustakaan sering kali digunakan untuk latihan lomba-lomba dan juga pembelajaran.

3) Sudut baca ramah anak disetiap kelas, disetiap ruang kelas yang terdapat sudut baca digunakan untuk menyimpan buku-buku pelajaran dan non pelajaran ramah anak dengan berbagai koleksi buku bacaan mulai dari cerita rakyat, dongeng, dan majalah. pihak sekolah membuat inovasi menarik yaitu pojok baca atau perpustakaan kecil yang disediakan didalam kelas untuk keperluan pustaka peserta didik [1].

4) Ruang kelas yang kaya teks literasi dan ramah anak, Ruang kelas di SD Negeri Brebes 03 selalu mengutamakan kenyamanan untuk peserta didik dalam belajar. Didalam ruang kelas terdapat tulisan yang kaya teks literasi guna untuk menumbuhkan minat baca peserta didik dan sebagai motivasi yang dapat dibaca oleh peserta didik.

5) Mading (majalah dinding), digunakan sebagai tempat untuk memajang hasil karya-karya peserta didik yang tidak lepas dari literasi seperti cerpen, puisi, pantun, gambar, dll. Dalam pelaksanaan GLS contoh program harian yaitu dengan membuat mading di perpustakaan sekolah sebagai media apresiasi karya anak [6].

6) Program perpustakaan keliling daerah, Pemerintah daerah Kabupaten Brebes memberikan pelayanan pepustakaan keliling untuk datang langsung ke sekolah-sekolah dasar dengan membawakan berbagai macam koleksi buku yang ramah anak. Perpustakaan keliling daerah Kabupaten Brebes digunakan secara langsung oleh peserta didik untuk membaca koleksi buku terbaru. Hal ini membuat suasana baru yang diberikan oleh pihak sekolah untuk peserta didik yang bosan untuk membaca buku-buku yang sama di perpustakaan maupun sudut baca kelas.

7) Pengadaan lomba literasi dilakukan guna mengembangkan minat dan bakat peserta didik dalam bidang literasi. Pihak sekolah selalu mengadakan lomba di ruang lingkup sekolah dan mengikuti perlombaan di luar sekolah. Dalam pelaksanaan GLS contoh program mingguan yaitu mengadakan kuis seperti lomba membaca, mendongeng, puisi, dan drama cerita rakyat yang menyenangkan [6]

\section{SIMPULAN}

Penelitian ini dapat disimpulkan yaitu, tahapan pelaksanaan gerakan literasi di sekolah dasar ramah anak meliputi tiga tahapan yaitu, tahap pembiasaan, tahap pengembangan, dan tahap pembelajaran. Semua tahapan GLS telah dilakukan secara teratur dan sesuai dengan standar SRA, namun pada tahapan pelaksanaan GLS mengalami perubahan penyesuaian terhadap kondisi pandemi covid-19. Dalam keadaan pandemi, sekolah belum bisa melakukan pembelajaran tatap muka seperti biasa dan kegiatan literasi menjadi kurang optimal. Program penunjang gerakan literasi di sekolah dasar ramah anak meliputi tujuh program yaitu, (1) Program 15 menit membaca, (2) Perpustakaan sekolah yang aman dan nyaman , (3) Sudut baca ramah anak disetiap kelas, (4) Ruang kelas yang kaya teks literasi dan ramah anak, (5) Program pembuatan mading, (6) Program perpustakaan keliling daerah, (7) Pengadaan lomba literasi. Penggunaan program penunjang tersebut sesuai dengan penerapan konsep SRA, dengan memperhatikan perkembangan dan kebutuhan peserta didik, serta keamanan dan kenyaman dalam pelaksanaan program tersebut.

Berdasarkan simpulan hasil penelitian, maka dapat dituliskan beberapa saran yaitu, (1) penelitian ini dapat dijadikan sebagai dasar dalam pelaksanaan implementasi GLS yang disesuaikan dengan penerapan SRA di sekolah dasar lebih lanjut. (2) pihak sekolah sebaiknya membentuk tim literasi sekolah yang secara khusus. (3) guru kelas tetap menjalin komunikasi yang baik dengan orang tua peserta didik. (4) guru dapat menambahkan buku bacaan ramah anak yang baru, (5) semua warga sekolah terus mempertahankan dan meningkatkan program-program GLS yang menyesuaikan dengan konsep SRA. (6) peserta didik lebih memanfaatkan program penunjang yang telah disiapkan oleh sekolah dan menerapkannya sesuai dengan konsep SRA. 


\section{DAFTAR PUSTAKA}

[1] R. N. Shoimah, "Implementasi gerakanliterasi di sekolah (studi kasus di SDN Karah 1 Surabaya)," MIDA : Jurnal Pendidikan Dasar Islam, vol. 3, no. 2, pp. 1-17, 2020, [Online]. Available: http://e-jurnal.unisda.ac.id/index.php/mida/article/view/984.

[2] A. Mumpuni and R. U. Nurbaeti, "Analisa Faktor yang Mempengaruhi Minat Baca Mahasiswa PGSD," DWIJA CENDEKIA: Jurnal Riset Pedagogik, vol. 4, no. 1, pp. 114124, 2020, [Online]. Available: https://jurnal.uns.ac.id/jdc/article/view/35229.

[3] P. Astuti, A. Mumpuni, and B. A. Pranoto, "Pengaruh Minat Dan Kemampuan Membaca Peserta Didik Dalam Memahami Teks Bacaan," Jurnal KONTEKSTUAL, vol. 1, no. 1, pp. 26-32, 2019, [Online]. Available: http://jurnal.umus.ac.id/index.php/kontekstual/article/view/55.

[4] N. Yuliyanti, R. U. Nurbaeti, and N. Afifah, "Efektivitas bahan ajar berbasis saintifik terhadap sikap ilmiah mahasiswa PGSD," Jurnal Ilmiah KONTEKSTUAL, vol. 2, no. 1, pp. $1-7, \quad 2020, \quad$ [Online]. Available: http://jurnal.umus.ac.id/index.php/kontekstual/article/view/242.

[5] M. Rapai, "Pengaruh gerakan literasi sekolah dan penerapan konsep sekolah ramah anak terhadap hasil belajar siswa pada mata pelajaran pendidikan agama Islam (penelitian pada siswa kelas V SDIT Miftahul Ulum Cinere, Depok)," Jurnal Ilmu Pendidikan Islam, vol. 2, no. 2, pp. 101-122, 2020, [Online]. Available: http://jurnal.fatahillah.ac.id/index.php/elmoona/article/view/20.

[6] M. Teguh, "Gerakan literasi sekolah dasar," Jurnal Pendidikan Dasar, vol. 1, no. 2, pp. 18-26, 2020, [Online]. Available: https://training.unmuhkupang.ac.id/index.php/jpdf/article/view/217.

[7] A. N. Soleh and L. Humaidi, Panduan sekolah dan madrasah ramah anak. Jakarta: Erlangga, 2016.

[8] H. Triaryanti and N. Hidayah, "Implementasi program gerakan literasi sekolah (GLS) ditinjau dari tahap pengembangan di SD Unggulan Aisyiyah Bantul," Jurnal Fundadikdas (Fundamental Pendidikan Dasar), vol. 2, no. 1, pp. 35-39, 2019, [Online]. Available: http://journal2.uad.ac.id/index.php/fundadikdas/article/view/817.

[9] A. Mumpuni et al., "Pengelolaan kegiatan GLS di sekolah dasar selama pandemi covid19," Jurnal Abdi Masyarakat UMUS, vol. 1, no. 2, pp. 58-63, 2021, [Online]. Available: http://jurnal.umus.ac.id/index.php/jamu/article/view/351.

[10] I. T. Yunianika and S. Suratinah, "Implementasi gerakan literasi sekolah di Sekolah Dasar Dharma Karya Universitas Terbuka," Jurnal Ilmiah Sekolah Dasar, vol. 3, no. 4, p. 507, 2019 , [Online].

Available: https://ejournal.undiksha.ac.id/index.php/JISD/article/view/17331. 